\title{
THE EFFECT OF WOK FAMILY CONFLICT ON EMPLOYEE PERFORMANCE: DOES INCOME MATTER OF INFLUENCE?
}

\author{
Navaneethakrishnan Kengatharan \\ University of Jaffna, Sri Lanka \\ kenga@univ.jfn.ac.lk
}

\begin{abstract}
Seminal research studies in the sphere of work family conflict lend credence to the notion that work family conflict is a deleterious factor hampering employee performance at work. Consequently, this study close looks at the moderating role of income in buffering the negative relationship between work family conflict and employee performance. Using a random sampling technique, a total of 124 employees working in apparel industry located in Trincomalee district were selected. Data were garnered using self-administrated questionnaire. The results revealed that the level of income moderated the relationship between work family conflict and employee performance. The results show that the negative relationship between work family conflict and performance is stronger with employees at low levels of income than those at high levels of income. This study makes a theoretical contribution to the frontiers of work family conflict and proffers practical implications that would serve as a springboard for future research studies.
\end{abstract}

Keywords: apparel industry, employee performance, in come, work family conflict 


\subsection{Introduction}

The work/family conflict research typically focuses on the difficulties employees have in balancing their work and family responsibilities (Adams, King, \& King, 1996). The interest in work and family conflict research studies has been fuelled by its negative consequences on individual employees and the organizations (Aryee, 1992; Frone, Russell, \& Cooper, 1992; Thomas \& Ganster, 1995). Previous studies have found that work family/conflict affects employee's selfdevelopment and career advancement (Jayaweera, 2005), absenteeism, tardiness, and poor work performance (Greenhaus \& Beutell, 1985; Frone, Russell, \& Cooper, 1997), low levels of general well-being (Aryee, 1992; Frone, Russell, \& Cooper, 1992), low levels of job satisfaction (Adams, King, \& King, 1996; Jayaweera, 2005; Grandey, Cordeiro, \& Crouter, 2005; Jayaweera, 2007); high levels of burnout (Burke, 1988), and more alcohol use and poorer health (Frone, Russell, \& Cooper, 1997), lower performance and employee turnover (e.g. Kossek \& Ozeki, 1998). Of late, economic, social, technological and global changes have become a breeding ground for incubating work family imbalance. The overriding fact is that the issue of work family conflict is more prevalent today than ever before.
Thus, the subject of how work/family conflict can be balanced has received significant attention by academics, employers, workers, politicians and the media.

In a nutshell, it is a pronounced notion that work family conflict is a militating factor against the success and survival of some organizations. Consequently, this study was designed to investigate whether the incomes employee received, can alleviate the effect of work / family conflict on employee performance. This study extends previous research by examining the moderating role of income on the relationship between work family conflict and employee performance.

\subsection{Theoretical underpinning}

Work/family conflict originated from role theory developed 50 years ago (Kahn et al., 1964) and it is defined by Greenhaus and Beutell (1985) as "a form of interrole conflict in which the role pressures from the work and family domains are mutually incompatible in some respects" (p.77). Therefore, the interrole conflict occurs when participation in one role consumes more resources (e.g. working long hours), which is incompatible with performance of another role (say leaving less time available for performing family role). 
Over the course of the past five decades, the conceptualisation of work/family conflict has changed. In the 1980s, work/family conflict was considered as a "unidirectional and one dimensional construct" by many researchers (e.g. Kopelman, Greenhaus, \& Connolly, 1983; Cooke \& Rousseau, 1984; Bedeian, Burke, \& Moffett, 1988), nonetheless, during the 1990s, the unidirectional model of work/family conflict was replaced by a bidirectionalmodelin terms of the sources of the conflict: work to family conflict (work interference with family) and family to work conflict (family interference with work) (e.g. Gutek, Searle, \& Klepa, 1991; Frone, Russell, \& Cooper, 1992; Williams \& Alliger, 1994; Netemeyer, Boles, \& McMurrian, 1996; Kelloway, Gottlieb, \& Barham, 1999; Carlson, Kacmar, \& Williams, 2000). Based on the seminal study of Greenhaus and Beutell (1985), Carlson, Kacmar and Williams (2000) brought the constructs of directions and dimensions together in a six dimensional model of WFC: work to family conflict including three forms (time- based, strain-based and behaviour-based) and family to work conflict including three forms (timebased, strain-based and behaviourbased). Time-based conflict refers to "time spent on activities within one role generally cannot be devoted to activities within another role" (Greenhaus \&
Beutell, 1985, p.77) and Strain-based conflict is defined as "roles are incompatible in the sense that the strain created by one makes it difficult to comply with the demands of another" (Greenhaus \& Buetell, 1985, p.80). The third form of work family conflict defined by Greenhaus and Buetall (1985) is behaviour-based conflict, in which "specific patterns of in-role behaviors may be incompatible with expectations regarding behavior in another role" (p.81). Consequently, work to family conflict is used to describe a conflict that is perceived to originate in the work domain and family to work conflict is used to describe a conflict that is perceived to originate in the family domain.

Therefore, work/family conflict is blended with spill-over and cross-over nature in situ. The spill-over is an intraindividual transmission of emotions / attitudes / stress/worries from one domain (say, work) to another domain (family), nonetheless, cross-over is dyadic and an inter-individual transmission (Westman, 2001). Work / family conflict has serious negative consequences on individuals, families and organisations. Inter alia, the crux of the problem is that the individual employee's performance can affect both organisational productivity and his/her career aspiration. Albeit many seminal 
studies found that work family/conflict affect employee performance (Ashfaq, Mahmood, \& Ahmad, 2013; Yavas, Babakus, \& Karatepe, 2008; Baum, 2007; Karatepe \& Kilic, 2007; Van Steenbergen, Ellemers, \& Mooijaart, 2007; Brownell, 1998; Frone, Russell, \& Cooper, 1997; Aryee, 1992; Kossek \& Nichol, 1992), thelevel of income reported as a motivator for the employee performance in many studies (e.g. Wholey, 1983). The level of pay is strongly dependent on justice theory: distributive justice (what they get) and procedural justice (how it is given) (e.g. Sweeney \& McFarlin, 1993; Colquitt et al., 2001). A few studies conducted in the past have established positive linkage between pay level and work family/conflict (e.g. Boyar et al., 2008; Bhave, Kramer, \& Glomb, 2013). This study argues that levels of income can moderate the relationship between work I family conflict and employee performance. It is therefore hypothesi-sed that level of income moderates the relationship between work family conflict and employee performance such that the negative relationship between work family conflict and employee performance will be stronger at the lower levels of income than those at higher level of income.

\subsection{Methods}

\section{Subjects}

Subjects for this study were chosen from employees working in apparel industries located in Trincomalee district. The required numbers of respondents were selected in terms of the total number of employees working in each apparel industry. Eventually, using a random sampling technique, a total of 200 questionnaires were issued. Of them, 166 questionnaires were returned (83\%), nonetheless, only 124 questionnaires were found to be usable (62\%). Sample made up of predomi-nantly females $67.7 \% \quad(\mathrm{~N}=84)$ and the remaining $32.3 \%$ of males $(\mathrm{N}=40)$. The level of income was grouped into two: low level and high level. $3.17 \%$ of employees were identified as low level of income earners and the remaining $62.9 \%$ were the high level of income earners.

\section{Measures}

A multidimensional/directional measure of work family conflict questionnaire developed by Carlson, Kacmar and Williams (2000) was used to measure work family conflict. Eighteen (18) questions composed the measure with three items for each dimension and both directions (work to family conflict and family to work conflict): time, strain 
and behaviour. Using a 5-point Likert scale, partici-pants were asked to indicate the extent to which they agree or disagree with each item. The responses range from 1 (strongly disagree) to 5 strongly agree. An example of an item from the time based work to family conflict scale was, "The time I must devote to my job keeps me from participating equally in household responsibilities and activi-ties" An example item from the time based family to work conflict scale was, "The time I spend on family responsi-bilities often interferes with my work responsibilities". In the current study, the Cronbach's alpha for work family conflict was 0.81 . Similarly, employee performance was measured using self-reported measures consisting of six questions using a five-point Likert scale from "much worse" (1) to "Much better (5).
Items include, for example; how do you rate the quality of your own work, It took me longer to complete my work task than intended and all in all I am performing well. In the current study, the Cronbach's alpha for employee performance was 0.79 .

\subsection{Results and discussion}

In this study, level of income has been hypothesised as a moderator of the relationship between work family / conflict and employee performance. More precisely, the negative relationship between work/family conflict and employee performance is stronger at lower levels of income than at higher levels of income. The results of the moderator analysis are presented in table 1.

\section{Table 01: Level of income as a moderator between work family conflict and employee performance}

\begin{tabular}{|l|c|c|c|c|}
\hline & $b$ & $S E B$ & $t$ & $P$ \\
\hline Constant & $6.31(5.38,7.24)$ & .47 & 13.41 & $\mathrm{p}<.05$ \\
\hline Level of income & $-3.28(-4.58,-1.99)$ & .66 & -5.01 & $\mathrm{p}<.05$ \\
\hline Work family conflict & $-.77(-1.03,-.51)$ & .13 & -5.86 & $\mathrm{p}<.05$ \\
\hline $\begin{array}{l}\text { Work family conflict x } \\
\text { Level of income }\end{array}$ & $1.01(0.67,1.41)$ & .19 & 5.60 & $\mathrm{p}=.0000$ \\
\hline & $R^{2}=.2847, M S E=.3986$, & \multicolumn{4}{|c|}{$F(3,120)=15.91, p=.0000$} \\
\hline
\end{tabular}


As shown in table 1, the interaction term (work family conflict x level of income) is significant, $b=1.01,95 \% \mathrm{CI}(.67$, $1.41), \mathrm{t}=5.60, \mathrm{p}<05$ revealing that the relationship between work family conflict and employee performance is moderated by the level of income.
Further, a slope analysis was conducted to understand the nature of moderating effect.

The result of the conditional effect of work/family conflict on employee performance at low and high levels of income is presented in table 2 .

\section{Table 02 : The result of the conditional effect of work family conflict on employee performance at levels of income}

Conditional effect of $\mathrm{X}$ on $\mathrm{Y}$ at values of the moderator

\begin{tabular}{|c|c|c|c|c|c|c|}
\hline Level of income & Effect & $\mathrm{SE}$ & $\mathrm{t}$ & $\mathrm{p}$ & LLCI & ULCI \\
\hline .0000 & -.7686 & .1312 & -5.8580 & .0000 & -1.0283 & -.5088 \\
\hline 1.0000 & .2749 & .1321 & 2.0813 & .0395 & .0134 & .5363 \\
\hline
\end{tabular}

As can be seen from the table 2, the results show two different regressions: the regression for work family conflict as a predictor of employee performance (1) when level of income is low (the level of income is noted as .0000); (2) at the high level of income (the level of income is noted as 1.0000). When the level of income is low, there is a negative relationship between work family conflict and employee performance, $\mathrm{b}=-.77,95 \% \mathrm{CI}(-1.02,-.51), \mathrm{t}=$ $-5.85, \mathrm{p}<0.05$ whilst at the high level of income, the relationship between work family conflict and employee performance is significantly positive $b=.27,95 \%$ , CI $(.01, .54), \mathrm{t}=2.08, \mathrm{p}<0.05$. Overall, results revealed that there is a significant negative relationship between work / family conflict and employee performance at the low level of income, nonetheless at the high level of income, there is a statistically significant positive relationship between work / family conflict and employee performance.

The analysis shows the effect of work/family conflict on employee performance. Results are shown under the following conditions: low level of income / low work/family conflict, low level of income / high work/family conflict, high level of income/ low work / family conflict, high level of income / high work/family conflict. The results are depicted in figure 1. 
Figure 01: Graphical presentation of levels of income as a moderator between work family conflict and employee performance

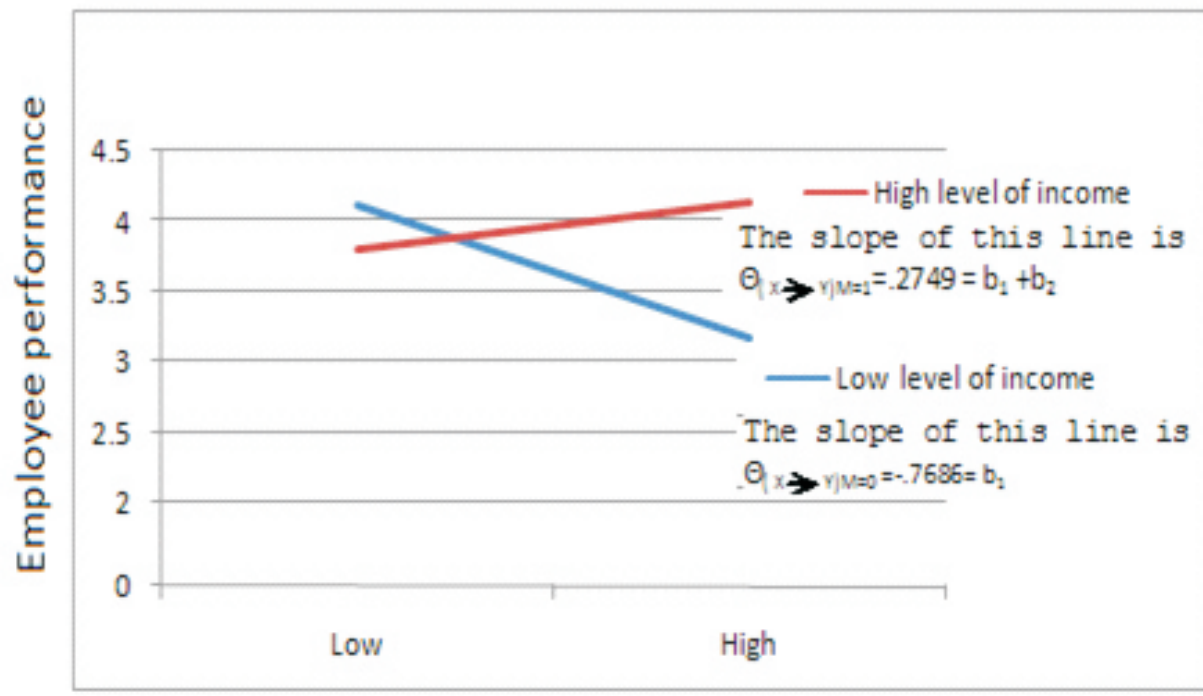

Work family conflict

From the figure 1, it can be seen that at the low level of work family conflict, employees show a slightly greater amount of employee performance at the low level of income than at the high level of income. Nonetheless, at the high level of work family conflict, employees report higher performance at the high level of income than the low level of income.

Overall, results revealed that income at all levels moderates the relationship between work/family conflict and employee performance. The negative relationship between work family conflict and employee performance found in many studies (e.g. Ashfaq, Mahmood, \& Ahmad, 2013; Yavas, Babakus, \& Karatepe, 2008; Baum, 2007; Karatepe \& Kilic, 2007; Van Steenbergen, Ellemers, \& Mooijaart, 2007) has turned into positive nature owing to the moderating effect of income at the high level of income. Consequently, the hypothesis that the level of income moderates the relationship between work family conflict and employee performance is supported. 


\subsection{Conclusion}

The overriding importance of this research study is the notion that the negative consequence of work/family conflict on employee performance can be mitigated by the level of income employees receive at apparel industries. In Sri Lanka, unemployment rate is at a high level and finding any good employment opportunities is difficult even for highly qualified candidates. The majority of the workforce working at the front lines are unskilled workers and get paid lower rates. Consequently, when they receive a high level of income they may express satisfaction and put more effort into getting next level of pay raise. This nature of relationship leads to the practical implication that organisations can pay significant attention to the level of pay employees receive in situations of work/family conflict. Moreover, this study makes a significant contribution to the frontier of work family literature as it focuses on the moderating role of income on the relationship between work/family conflict and employee performance in apparel industries. Furthermore, this research sheds light on the role of income in alleviating the harmful effects of work/family conflict on employee performance. Albeit the research has provided useful insights and contributions to work/family conflict, there are limitations. The major limitation was the cross sectional research design that makes it difficult to definitely identify causal relationships and therefore firm conclusions. Future studies may consider adopting a longitudinal approach. Moreover, a more detailed study across organisations, occupations and nations with similar culture is warranted for further validation, replication and genera-lisation.

\subsection{Acknowledgement}

I gratefully acknowledge my debt to Sudirikku Jayaweerage Chathurangani Samanthika for her unstinting support and sincere involvement in the data collection process. 


\section{References}

Adams, G. A., King, L. A., \& King, D.W. (1996). Relationships of job and family involvement, family social support, and work-family conflict with job and life satisfaction, Journal of Applied Psychology, 81(4), 411-420. doi:10.1037/00219010.81.4.411

Aryee. S. (1992). Antecedents and Outcomes of Work-Family Conflict Among Married Professional Women: Evidence from Singapore, Human Relations,45(8), 813-837. doi.10.1177/001872679204500804

Ashfaq, S., Mahmood, Z., \& Ahmad, M. (2013). Impact of Work-Life Conflict and Work Overload on Employee Performance in Banking Sector of Pakistan, Middle-East Journal of Scientific Research, 14(5), 688-695.

Baum, T. (2007). Human Resources in Tourism: Still Waiting for Change, Tourism Management, 28(6), 1383-1399. doi:10.1016/j.tourman.2007.04.005

Bedeian, A. G., Burke, B. G., \& Moffett, R. G. (1988). Outcomes of work-family conflict among married male and female professionals, Journal of Management, 14(3),475-491. doi:10.1177/014920638801400310

Bhave, D. P., Kramer, A., \& Glomb, T. M. (2013). Pay satisfaction and work-family conflict across time, Journal of Organizational Behavior, 34(5), 698-713. doi:10.1002/job.1832

Boyar, S. L., Maertz Jr, C. P., Mosley Jr, D. C., \& Carr, J. C. (2008). The impact of work/family demand on work-family conflict, Journal of Managerial Psychology, 23(3), 215-235. doi: 10.1108/02683940810861356

Brownell, J. (1998). Striking a Balance: The Future of Work and Family Issues in the Hospitality Industry, Marriage and Family Review, 28(1 \& 2), 109-123. doi: 10.1300/J002v28n01_06

Burke, R. J. (1988). Some antecedents and consequences of work-family conflict, Journal of Social Behavior and Personality, 3(4), 287-302. Retrieved from https://search.proquest.com/docview/1292297418?accountid=14557

Carlson, D. S., Kacmar, K. M., \& Williams, L. J. (2000). Construction and Initial Validation of a Multidimensional Measure of Work-Family Conflict, Journal of Vocational Behavior, 56(2), 249-276. doi:10.1006/jvbe.1999.1713

Colquitt, J. A., Conlon, D. E., Wesson, M. J., Porter, C. O. \& Ng, K.Y. (2001). Justice at the millennium: a meta-analytic review of 25 years of organizational justice research, Journal of applied psychology, 86(3), 425-445. doi: 10.1037/00219010.86.3.425 
Cooke, R. A., \& Rousseau, D. M. (1984). Stress and strain from family roles and workrole expectations', Journal of Applied Psychology, 69(2), 252-260. doi:10.1037/0021-9010.69.2.252

Frone, M. R., Russell, M., \& Cooper, M. L. (1992). Antecedents and outcomes of work-family conflict: Testing a model of the work-family interface, Journal of Applied Psychology,77(1), 65-78. doi:10.1037/0021-9010.77.1.65

Frone, M. R., Russell, M., \& Cooper, M. L (1997). Relation of work family conflict to health outcomes: A four- year longitudinal study of employed parents, Journal of occupational and organizational psychology, 70(4), 325-335. doi:10.1111/j.2044-8325.1997.tb00652.x

Grandey, A., Cordeiro, B., \& Crouter, A. (2005). A longitudinal and multi-source test of the work-family conflict and job satisfaction relationship, Journal of Occupational and Organizational Psychology, 78(3), 1-20. doi: 10.1348/096317905X26769

Greenhaus, J. H., \& Beutell, N. J. (1985). Sources of conflict between work and family roles, Academy of management review, 10(1), 76-88. doi: 10.5465/ AMR. 1985.4277352

Gutek, B.A., Searle, S., \& Klepa, L. (1991). Rational versus gender role explanations for work-family conflict, Journal of Applied Psychology, 76(4), 560-568. doi: 10.1037//0021-9010.76.4.560

Jayaweera. A. T. (2005). Management Development: A Model of Linkages between Work Family Conflict, Job Satisfaction and Individual's Passionate Desire to Develop through Management Development Opportunities, SAARC Journal of Human Resource Development, 108-116.

Jayaweera, A.T. (2007). Examining the relationship of job satisfaction and work family conflict with job performance of Sri Lankan hotel managers, Fourth international conference on Business and management (March), University of Sri Jayewardenepura, Sri Lanka, 183-189.

Karatepe, O. M., \& Kilic, H. (2007). Relationships with supervisor support and conflicts in the work-family interface with selected job outcomes of frontline employees, Tourism Management, 28(1), 238-252. doi: 10.1016/j. tourman. 2005.12.019

Kelloway, E. K., Gottlieb, B. H., \& Barham, L. (1999). The source, nature, and direction of work and family conflict: A longitudinal investigation, Journal of Occupational Health Psychology, 4(4), 337-346. doi:10.1037/1076-8998. 4.4.337 
Kopelman, R. E., Greenhaus, J. H., \& Connolly, T. F. (1983). A Model of Work, Family, and Inter-Role Conflict: A Construct Validation Study, Organizational Behavior and Human Performance, 32(2), 198-215. doi:10.1016/00305073(83)90147-2

Kossek, E. E., \& Nicol, V. (1992). The effects of on-site child care on employee attitudes and performance', Personnel Psychology, 45(3), 485-509. doi: 10.1111/j.1744-6570.1992.tb00857.x

Kossek, E. E., \& Ozeki, C. (1998). Work-Family conflict, policies, and the job life satisfaction relationship: A review and directions for future organizational behavior-human resources research, Journal of Applied Psychology, 83(2), 139149. doi: 10.1037/0021-9010.83.2.139

Netemeyer, R. G., Boles, J. S., \& McMurrian, R. (1996). Development and validation of work-family and family-work conflict scales, Journal of Applied Psychology, 81(4), 400-410. doi:10.1037/0021-9010.81.4.400

Sweeney, P. D., \&McFarlin, D. B. (1993). Workers' Evaluations of the" Ends" and the" Means": An Examination of Four Models of Distributive and Procedural Justice, Organizational behavior and human decision processes, 55(1), 23-40. doi: 10.1006/obhd.1993.1022

Thomas, L. T., \& Ganster, D. C. (1995). Impact of family-supportive work variables on work-family conflict and strain: A control perspective, Journal of Applied Psychology, 80(1), 6-15. doi: 10.1037/0021-9010.80.1.6

Van Steenbergen, E. F., Ellemers, N., \& Mooijaart, A. (2007). How work and family can facilitate each other: Distinct types of work-family facilitation and outcomes for women and men, Journal of Occupational Health Psychology, 12(3), 279300. doi: 10.1037/1076-8998.12.3.279

Westman, M. (2001). Stress and strain crossover, Human Relations, 54(6), 717-751. doi: $10.1177 / 0018726701546002$

Wholey, J. S. (1983). Evaluation and Effective Public Management, Boston: Little, Brown and Company.

Williams, K., \&Alliger, G. M. (1994). Role stressors, mood spillover, and perceptions of work-family conflict in employed parents, Academy ofManagement Journal, 37(4), 837-868. doi:10.2307/256602

Yavas, O., Babakus, E., \& Karatepe, O. M. (2008). Attitudinal and behavioural consequences of work-family conflict and family-work conflict. Does gender matter?' International Journal of Service Industry Management, 19(1), 7-31. doi: 10.1108/09564230810855699 